\title{
Industrialization in Sub-Saharan Africa and import substitution policy
}

\author{
ANA PAULA F. MENDES \\ MÁRIO A. BERTELLA \\ RUDOLPH F. A. P. TEIXEIRA*
}

This article aims to contribute to the understanding of the process of import substitution in Sub-Saharan Africa. The process of industrialization in Sub-Saharan Africa occurred in two phases: a first step, even very early during the colonial regime began around the 1920s and ended in the late forties; a second phase of industrialization began in the late fifties and gained momentum in the sixties, when import substitution was implemented more widely. Although these countries were the last to embark on the strategy of import substitution, they followed the same steps of Latin American countries, and as the structural domestic and external constraints were too strong, the failure of the policy of import substitution arrived early and the negative impact on these economies had a greater magnitude.

Keywords: Sub-Saharan Africa; import substitution; industrialization.

JEL Classification: N67; O14; O25.

\section{INTRODUCTION}

Import substitution was one of the development strategies which started to prevail as a form of industrialization in most developing countries in the post-war period. In many Latin American countries, especially Brazil, Mexico, and Argentina, a conscious implementation of import substitution policies was observed as of the 1950s and early 1960s. Soon after independence, countries of Sub-Saharan

\footnotetext{
* Respectivelly, Millenium Challenge Account Cape Verde (MCA-CVII). E-mail: anafmendes@yahoo. com.br; PhD Professor at FCLAR/UNESP. E-mail: mabertella@yahoo.com.br; Analyst at Eletrobras. E-mail: rudolphgp@hotmail.com or rudolph.teixeira@eletrobras.com. Submitted: 20/December/2011; Approved: 5/June/2013.
} 
Africa identified themselves ideologically with that strategy, and began to implement it in the subsequent years; in fact, that was the only strategy associated with the ideology of development originated with the independence process in African nations. Nevertheless, how that process occurred in African countries and why it was not very successful are still not well known.

In the first half of the 1960s, Tanzania, Zambia, and Nigeria began to implement the import substitution industry on a large scale; afterwards, the implementation of this strategy was noted, among other countries, in Ghana and Madagascar and up to the 1980s import substitution was observed in the other Sub-Saharan countries.

The way in which that process occurred in the Sub-Sahara is much less clear than that in Latin America, for most countries of that region in the African continent gained independence only in the late 1950s and 1960s, and little attention was given to them in the literature at the time. Although those countries were the last ones to embark on the strategy of import substitution, they followed Latin America countries' steps, and as structural domestic and external constraints were stronger, the policy of import substitution soon failed, having a more profound impact on their economies.

Contrary to popular opinion, African manufacturing began to develop as from the beginning of the $20^{\text {th }}$ century, more specifically in the 1920 s, still during the colonial period. The industrialization process in Sub-Saharan Africa occurred in two phases: the initial stage, a very incipient one still during colonialism, stimulated by colonial people, started around that time and ended in the late 1940s; the second stage of industrialization began in the late 1950s and gathered momentum in the 1960s, when import substitution was more widely implemented. In the latter period, industrialization, as in Latin America, is a politically conscious strategy aimed at overcoming underdevelopment. In the Sub-Saharan region, the process of import substitution followed the dynamic typical of any import substitution process. That strategy lasted until the second half of the eighties due to a structural adjustment policy which strongly disapproved of that industrialization system for the region.

The purpose of this paper is to add to the understanding of the Sub-Saharan import substitution process. It has been, therefore, organized as follows: the initial stage of the industrialization strategy in Sub-Saharan Africa is presented in the first section; the second stage of that process is described in the following section; the contributing factors to the failure of import substitution are pinpointed in the third section; results are shown in the next section; lastly, a brief conclusion is drawn focusing on the major hindrances to that process in the region.

\section{INITIAL STAGE OF THE INDUSTRIALIZATION}

The road to the first stage of the industrialization process in Sub-Saharan Africa was long, and paved with a great deal of conflict of interests between national and international economic agents. International agents were engaged in activities 
linked with imports, manufactured goods trading in the colonies, production and export of primary products from the colonies to the metropolises, and the international market. This group of agents comprised the metropolitan bureaucracy, major import/export traders, and major domestic corporations owned by colonial people.

National agents were involved with agricultural (on smaller farms), trading, and craft activities, and showed interest in local development. This group of agents consisted of small corporations owned by colonial people, small farmers, autochtones, small traders, immigrants from India and Lebanon, and other Arabs.

Until 1949, international agents and particularly local colonial Governments had never encouraged the introduction of a vigorous industrial policy in African colonies. This type of policy would come into conflict with the main mission of European rulers to provide the metropolis with a market for their manufactured goods and supply of cheap raw materials. On the other hand, major European trading firms kept their commitment to the flow of products from the colonies to the international market in the name of the metropolis. Moreover, these big traders managed to survive due only to the vicissitudes of the international market and the instability of African commodity prices, fully exploiting local producers. As a result, they had become extremely careful and hesitant to change from high liquidity export/import investments to risky investments in fixed capital with a low level of liquidity in African markets, which they knew were limited to the few Europeans residing there.

Improvement in the transportation connecting Africa to European metropolises had immediate effect on the reduction of transfer costs of manufactured goods from the center to colonies and raw materials from the latter to metropolises. Easy access to imports explained why there was no incentive to develop local manufacturing. Domestic metropolitan Governments regarded themselves as prime representatives of the metropolitan economies which benefited from an existing trade model, and their point of view was reflected in policies blocking the efforts put into local industrialization.

Austen (1987) states, however, that a genuine effort towards industrialization was in fact still non-existing, for there was no pressure from national agents, colonial people, local traders and craftsmen, or immigrants, who identified their interests with the development of an internationally competitive industry. The same author warns that lack of pressure did not mean lack of local business, but rather an absence of competition between domestic businessmen and foreign groups. This national apathy was due to the domestic agents' incapacity to react to structural and price constraints imposed on them by big businesses. A reduction in the price of imported goods, for example, put an end to their markets for textiles, natural colorants, rubber and metal fragments. Craft businesses, unable to compete, had to adjust their production and, therefore, began to operate in a complementary way or quite independently from the European businesses. In the production of textiles, for instance, they started to produce cheaper fabric, which was a step backwards, for they began to make thinner clothing instead of finer materials.

Major farm and mine owners did not show much interest, either in investing 
in local manufacturing for local or international markets. As Pearson (1969) and Kilby (1975) comment, the view of that business class was that the African industry was not going to increase its oil and ore consumption significantly. They did not believe either that investment in African manufacturing would generate bigger profits than those obtained through exports of African raw material and commodities to the international market and imports of manufactured goods for consumption in Africa; this means that they did not have any perception that manufacturing would generate profits big enough to justify a change in activity. As a matter of fact, the only direct incentives for the industry provided by the agricultural and mining sectors were associated with complementary industrial activities, such as the manufacture of inputs for metal processing and extraction, and tools for agriculture.

Nevertheless, a growth in the agricultural sector and its exports generated profits which could be invested in manufacturing, instead of being reinvested in crops, and also created a tax basis for the Government which could be invested in manufacturing activities, especially the manufacture of consumer goods, and input products for agriculture and mineral extraction activity. Moreover, the agricultural sector provided African workers with fairly higher salaries and social benefits, which resulted in an income rise, thus increasing the demand. Local businessmen, in turn, were favored, even though imports met most demand. That was precisely what gave the colonial people the power they needed as manufacturing incentive.

It was in this economic environment that in the 1920s the first stage of industrialization began in Sub-Saharan Africa. The beginning of industrialization was made possible only because countries such as the Belgian Congo (present name Brazzaville Congo), South Rodhesia (now Zimbabwe), and Kenya - which were less controlled by the metropolis - began to produce, domestically and on a small scale, products which contained a considerable amount of local raw material, such as textiles, bottles, soap, and cigarettes (Coulson, 1982; Forrest, 1982). Interest and the need for import substitution were expressed by colonial people who had more political power than immigrating businessmen - Lebanese, other Arabs and people from India - and the autochton artisan population. From that period on, these colonial people sought local Government's adherence and support, both formal and informal, and managed to obtain tariffs to protect the local market, thus paving the way for a long, slow process to promote the development of manufacturing. ${ }^{1}$

In 1927, filled with enthusiasm at the thought of moving the internal forces to start a new form of capital accumulation, and envisioning a broader market, those countries, together with Tanzania, Uganda, and Zaire (now the Democratic Republic of the Congo) created the East African common market ${ }^{2}$ and the Central African

\footnotetext{
${ }^{1}$ In fact, the great support local colonial people needed to develop manufacturing would only come in the late 1940s.

${ }^{2}$ East Africa's market was formed by Tanzania, Uganda, and Kenya. The South Federation was formed by Rhodesia (now Zimbabwe), Nyasiland (now Malawi), and Bechuanaland (now Botswana). Central
} 
common market. In these markets there was: i) free circulation of manufactured, agricultural and mining goods; ii) some manufacturing complementarity between nations; and iii) common trading tariffs in the common market, and from that to the external market. However, in most of the continent, a colonial policy continued to prohibit the establishment of manufacturing businesses, unless they were essentially related to crops for export.

Nevertheless, this incipient process was interrupted by the 1930's crisis as the industrial interests of the metropolises, particularly in England, prevented investments in manufacturing for the local market - a regressive step in the process the countries above had begun, with the exception of Zimbabwe. Due to the Great Depression, the price for Sub-Saharan Africa's crop exports fell sharply, thus causing income of the colonial Governments to drop dramatically; in spite of that, stimulus to industrial development was not allowed to expand, especially in Tanganyica (now Tanzania) which was taking the first steps in that direction. Contrarily, in several colonies, the Government cut costs and continued to enlarge the crop production in order to export more and compensate for price reduction, thus suffocating manufacturing that was beginning to develop (Kilby, 1975; Coulson, 1982; Forrest, 1982).

The world crisis of the 1930s renewed the colonial people's interest in the development of manufacture; this time they led a large movement supported by colonial bureaucracy, and therefore were more successful. Colonial bureaucracy supported the movement because they felt the crisis in the metropolises posed a threat to their privileged status in the colonies - their jobs and other incomes their position offered - and colonial people, especially owners of small and mediumsized land, were in danger of losing the land granted to them centuries before for farming. That huge movement led to the establishment of investments by metropolitan businessmen in association with colonial people in the manufacture of fairly light consumer goods.

From the Second World War on, relations between metropolises and colonies changed drastically. In central countries, synthetic substitutes for cotton, sisal, and rubber began to be made from petroleum, in addition to other agricultural raw materials such as fertilizers, which were chemically produced. Petroleum and foodstuffs became primary strategic products, none of which were exported from the colonies to the centers, thus causing the metropolises to realize that there was no longer any economic need to keep the colonies and/or invest in their growth. As a result, not only colonial Governments but also local businessmen had more freedom to take the measures that best suited their own interests and economic needs.

The Korean War, between 1950 and 1953, generated a severe shortage of most raw materials, resulting in higher prices for primary goods, which in turn increased

Africa's market was formed by Zambia and North Rhodesia (Stoneman, 1982). Later, in 1950, the Economic Community of the West African States was created, comprising Nigeria, Benin, the Ivory Coast, Ghana, Niger, and Chad, among other West African countries (Forrest, 1982). 
the income of the colonies and their foreign exchange available for imports. However, at the same time, the war created a shortage of consumer goods in the capitalist centers, including England, thus making it impossible to supply the colonies with these goods (Coulson, 1982; Forrest, 1982). It is precisely these metropolises' inability to provide the colonies with consumer goods that made the metropolitan Governments decide to encourage production in order to substitute imports in all African regions; therefore, near the fifties, foreign businesses began to invest in other colonies, especially in Kenya, Tanzania, Nigeria, the Ivory Coast, Ghana, and Senegal, among others - in addition to Zimbabwe which, according to Arrighi and Saul (1973), already received large foreign investments.

The beginning of the import substitution process was timid, and favored the mining industry and crop processing, activities which were already being benefited from 1945 on. These sectors were chosen due mainly to the small size of the African markets, the population's low income, and the lack of infrastructure in the local industry; in fact, as the primary exportation model favored major colonial people - who had no interest in promoting infrastructure and basic services - investments of foreign capital in these sectors were small and targeted at exports.

It was clear that this initial stage of industrial development involved conflicts of interests between national and international orientation — of the metropolitan Government and international business groups - producing a "stop and go" effect on the process - that is, making the process alternate between progression and regression. Since one of the objectives of the metropolitan policy was to hinder the process in order to monopolize the manufactured goods market, Sub-Saharan African countries came into the 1950s without actually having what could be defined as "basic" industry, not even at a very low level. It can be therefore stated that for most of the region, at that stage, industrialization had been nothing but unsuccessful attempts.

This analysis allows us to discuss the challenges African Governments would face the moment they gained independence and committed themselves to developing their nations, primitive and impoverished by colonial policies. The first problems they would have to deal with when they tried to devise an industrialization plan would be: i) a nonexistent local business class; ii) reduced savings capacity; iii) absence of human capital; and iv) no knowledge of technology.

\section{SECOND STAGE OF INDUSTRIALIZATION}

In the early 1960s, in the wake of the independence, Sub-Saharan Africa still had a primary exportation economy. The dynamism of its development depended on the demand for their export commodities by the central countries. The exporting activity was concentrated in a small number of products - crops and minerals - which made the region extremely vulnerable to crises in the ex-metropolises with which they maintained trade relations, and volatile international prices for their products. 
It must be pointed out that, in most countries, the Government assumed the leadership of completely impoverished economies with little or no public finance, virtually without key institutions to run a country, an acute shortage of physical and human capital - a high illiteracy rate, $71.7 \%$ in 1970 (World Bank, 1994) - and a huge mass of inexperienced and unskilled workers; in addition to these factors, there was no domestic savings, and infrastructure was poor.

In this context, the second stage of Sub-Saharan Africa's industrialization, which starts soon after the period of change in power from the metropolises to the autochton population ${ }^{3}$ arises from an anti-colonial ideology, anti-exploitation, and a rupture with foreign capital, seen as neocolonial. It was in the presence of such constraints and the pressure of declining terms of trade for primary goods - which reduced their import capacity even more - that new policies began to counteract the severe underdevelopment. The new African Governments, confronted with the calamitous situation of their countries, concluded that the road to development was to base their economies on new production activities in other sectors. On contemplating the fairly successful development in the Latin American countries, they decided to adopt import substitution as a strategy to overcome poverty in the region; therefore, the sixties mark the first attempt at an industrialization policy for most countries in Sub-Saharan Africa.

The new nationalist Governments would try to finance industrialization, for — in their ideology — industry would be the driving force behind the transformation of economies - predominantly agrarian and primitive - into modern economies less dependent on international markets. Kilby (1975), and Mkandawire and Soludo (1999) suggest that import substitution was the original industrialization policy, because the Governments recognized that they did not have the capability to compete in the world market. The objective was to ban the export structure based on obsolete farming, and use import substitution as support to expand and diversify its production.

With import substitution, imported goods would begin to be produced domestically and the negative effects of the declining terms of trade would be minimized, thus partly solving the disequilibrium in the balance of payments. It was believed that in the long run adverse terms of trade would be reverted by shifting the export structure from primary goods to goods whose prices tended to be higher, and had less elasticity of demand; to achieve that, the ultimate goal of the Governments was to: encourage foreign investment; ${ }^{4}$ acquire new technologies from central countries to diversify the industry later on; and, by orienting themselves outwards, to expand

\footnotetext{
${ }^{3}$ In the period between the late 1950s and early 1960s, Sub-Saharan Africa was the least industrialized region in the world according to World Bank (1994).

${ }^{4}$ What may seem contradictory in principle, but economic need is greater than ideologies, as it will be explained soon hereafter.
} 
the export list, and gradually enter the international market of competitive manufactured goods. ${ }^{5}$

\section{IMPORT SUBSTITUTION FINANCED BY EXTERNAL AND PUBLIC RESOURCES}

The Governments, aware of the constraints previously pointed out, especially the shortage of domestic savings by most of the countries, decided not to part from foreign capital definitively, recognizing that it would be crucial to the acquisition process of resources to finance the plants that would constitute the industrial park, the procurement of technology from industrialized countries, and the certainty of staff to manage the businesses and coordinate their production lines. They also recognized that a rupture with ex-metropolises would affect the obtainment of resources - in the form of aid - from international institutions by the State. It is the financial aid, actually, that would set in motion part of the ambitious development plan devised by these countries, particularly for their industry.

Therefore, in the early 1960s, the Governments took steps not only to expand foreign businesses ${ }^{6}$ from their initial base in the - external and internal - commercial sectors, and distribution to the manufacturing sector, but also to attract more private foreign capital. As pointed out by Stein (1992), the public policy to stimulate foreign investment encompassed the following measures: tax exemption, preferential access to credit, low customs duty rate, favorable exchange rate for investors, and duty-free import of capital goods.

These actions resulted in the installation of a capital-intensive technology. Therefore, following a typical import substitution model, a capital-based industry was established, sacrificing a comparative advantage in the use of labor and natural resources. ${ }^{7}$

Foreign capital was directed at industries that produced nondurable consumer goods, and industries that produced goods which could not be imported, such as the construction material industry and that of some mineral processing. Nevertheless, the imported technology was lucrative only for large-scale production, that is, it was technology developed for mass consumption. As the market was small in Africa, due mainly to low income, there was no public for manufactured goods, thus making production at profitable levels unviable. Multinationals tried to export manufactured goods in the region, but lack of a transportation infrastructure con-

\footnotetext{
${ }^{5}$ According to Mkandawire and Soludo (1999), African Governments intended that manufactured goods would become the main providers of foreign currencies in the future, as their prices fluctuated less than those of primary goods.

${ }^{6}$ That does not mean that, during this period, there was no domestic investment in manufacturing. The State began to invest in enterprises by virtue of revenues obtained through primary goods exports.

${ }^{7}$ What would result, sooner or later, in negative implications for the current account, and affect the sustainability of the industry itself.
} 
necting the countries that shared a border, and poor port conditions were obstacles to exportation to the other countries of the region. The multinationals noticed these difficulties right from the beginning, and changed the course of their activities, concentrating on the exploration of valuable minerals and petroleum. ${ }^{8}$

Since foreign capital was being favored, the exiguous local private capital played a minor role in development at this industrial stage. Its activities were concentrated on small-scale production, trading, regional distribution, and also on the transportation sector. In spite of the fact that it was not supported, this class was not liquidated, and would form a local faction with nationalist ideas. Although at first avoided by the State, that group would ally themselves with the Government in the creation of parastatals - in some countries. ${ }^{9}$

The data presented by Pearson (1969) show that the industry grew considerably during that period. In DR Congo, the average annual growth rate of the industry was 11\% between 1948 and 1959; in Zimbabwe, its average annual growth rate was 8.7\% between 1948 and 1963; in Nigeria, 6\% between 1950 and 1957; and in Kenya, 5\% between 1956 and 1963 . With regard to Zimbabwe, between 1945 and 1965, the share of manufacturing in GDP rose from almost 3\% to $20 \%$, while that of the mining sector fell from approximately $13 \%$ to $7 \%$, and agriculture, from $20 \%$ to $12 \%$ (Stoneman, 1982, p. 282; Coulson, 1982).

Pearson (1969) indicates that the countries of the East African Union - Kenya, Uganda, and Tanzania - already had very diversified manufacturing in 1963 and 1964. In the nondurable goods sector - foodstuffs, drinks, tobacco, textiles, shoes, clothing, paper, and leather were produced; in the intermediate goods sector - rubber, chemicals, oil, electrical materials, and metal and non-metallic mineral products; and in the capital goods sector - some electrical machines and transportation equipment.

Coulson (1982), however, mentions that, in the late first half of the 1960s, the Governments were dissatisfied with the problems of the balance of payments, and the behavior of foreign capital. Current account balance showed a large deficit because the import substitution process required a great import of machines, parts, and other intermediate inputs for production, in addition to skilled labor, thus causing great pressure on external accounts. With respect to foreign capital, there was a negative flow between the inflow and the outflow of foreign exchange - see Tanzania's example on table 1. Moreover, foreign businesses preferred importing synthetic inputs - produced in central countries and used for production - to

\footnotetext{
${ }^{8}$ According to Gulhati and Sekhar (1982), in Kenya and Zambia, the multinationals set up industries that produced goods intended for export. In Zambia, these businesses were nationalized from the second half of the 1960s on, and began to produce only for the internal market. Something similar occurred in Tanzania.

${ }^{9}$ According to Stein (1992), the educated elite joined politics and bureaucracy, and held positions that provided them with other sources of income, trading, and property, establishing a boss-customer relationship - it is the example of their alliance with foreign capital based on patronage. This limited the nationalist opposition to the dominion of the foreign capital over the economy.
} 
using natural domestic inputs (such as rubber and sisal), overburdening the balance of current account, and also breaking the connection between sectors. That made it difficult for the various activities to grow internally, and prevented the natural expansion of the economy and the income.

Table 1: Outflow of Gross Profit and Inflow of Private Capital between 1961 and 1968 in Tanzania and other developing countries (in millions of local currency)

\begin{tabular}{|c|c|c|}
\hline Year & Tanzania & Other Developing Countries \\
\hline 1961 & -71 & 50 \\
\hline 1962 & -73 & 58 \\
\hline 1963 & -123 & 155 \\
\hline 1964 & -93 & 79 \\
\hline 1965 & -110 & -6 \\
\hline 1966 & -114 & 138 \\
\hline 1967 & -159 & -66 \\
\hline 1968 & 114 & 76 \\
\hline Total & -629 & 484 \\
\hline
\end{tabular}

Source: Rweyemamu (1971, p. 115), cited by Coulson (1982, p. 67).

In general, it was noticed that foreign capital and the market would not provide the economic transformation required to overcome underdevelopment effectively. As stated by Nixon (1982, p. 45),

import substitution did not relieve the constraints of the balance of payments significantly; it led to an increase in the dependency of large imports of capital-intensive technology [...], the process was heavily dependent on foreign capital.

It was then that nationalist groups emerged and decided to change the course of the economic policy by opting for a nationalized process of import substitution.

\section{Import Substitution Led by the State}

In general, from the second half of the 1960s on, the Governments assumed total control of the industrial development, and introduced several modifications to the institutions and the economic policy. Herbst (1990) and Stein (1992) comment that the economic policy adopted two guiding principles: the first one was related to the foreign trade policy, and emphasized three aspects: i) multiple exchange rates effectively choosing imports, giving preferential treatment to capital and intermediate goods, and certain basic inputs, strongly discriminating luxury goods; ii) imposition of administrative import control through quotas, licenses, and tariffs; and iii) price control and prohibition of imports of goods similar to those produced domestically. The second guiding principle was an investment policy, for 
which the State defined three priorities: i) to make large investments in manufacturing; ii) to create and widen the basic infrastructure for the industry; and iii) to orient towards basic investments through the creation of public institutions connected exclusively with industrial development. The purposes of these institutions were as follows: to stimulate foreign businesses to retain the profit in the country by reinvesting productively in the manufacturing sector, otherwise they would be controlled by the Government; to nationalize banks and insurance companies dominated by foreign capital; to gather and allocate domestic savings; and to manage official foreign aid and the projects funded within the scope of the aid.

At the time, the nationalization process of foreign businesses was part of a strategy by the Governments as a result of some factors: first, it was closely associated with the State's dissatisfaction with the foreign businesses that sent the profits to their countries of origin instead of reinvesting them productively, and the small number of jobs created by those businesses. The second aspect was related to the ideological change by several countries, such as Tanzania, Zambia, Ghana, among many others, tending towards a socialist orientation or something similar (Forrest, 1982; Gulhati \& Sekhar, 1982; Coulson, 1982).

Ghai (1991), and Paulson and Gavin (1999) mention that, due to the nationalization wave, the Governments began to favor public capital and private domestic capital, encouraging the latter to ally itself to the State by participating in the formation of parastatals - which occurred in less radical socialist countries. Thus, participation of the local population in the management of businesses also began to be stimulated, concomitantly with the rejection of management by foreigners - including in Kenya and the Ivory Coast, which had a more capitalist orientation. Some subterfuges were, therefore, used, such as: i) deny nationality to alien minorities; ii) demand work permit to non-nationals; and iii) impose restrictions on foreign businesses in the trading, distribution, and transportation sectors.

Thus, behind industrialization lay production for the domestic market and the creation of jobs, which began to be considered more important to the point where some Governments proposed autarky. The most radical ones forgot about their initial goal, that the import substitution process was a means of organizing and diversifying the domestic production core, in addition to serving as an orientation, later on, towards the international market. As a result, the State turned its full attention to industry, and made great investments in factories for large-scale production, some of which in association with foreign capital and/or national capital. This made the industrial park expand considerably, with the multiplication of the number of plants intended mainly for the production of nondurable consumer goods — such as textiles, paints, plastics, light drinks, beer; construction materials — such as ceramics, faucets, pipes, floor tiles, roof tiles; pharmaceuticals; fertilizers and agro-industrial products. The exploration of minerals, such as iron, was also expanded, and the State invested in oil production and petroleum-based products.

D'Almeida (1986, p. 56) indicates that the number of state-owned companies in Tanzania, for example, rose from 80 in 1967 to 400 in 1981. In Kenya, they increased threefold, from 20 - at the time of independence in 1963 - to 60 in 
1969. In Ghana, where there were no state-owned companies at its independence in 1959, there were approximately 100 in the early 1960s. In other countries, such as Zambia, Senegal, the Ivory Coast, Mali, Mauritania, and Uganda, there was a marked increase in the number of those companies. ${ }^{10}$

Moreover, Short (1984, p.118) shows data for that period, which suggest that the share of the state-owned companies in the GDP of Sub-Saharan African countries was larger than that of other developing countries $-17.5 \%$ against $8.6 \%$ - and that the share of the state-owned companies in fixed capital formation was almost $17 \%$ higher than the average value of developing countries.

The oil shock in 1973 posed serious problems for the balance of payments, and although it was weakened, the import substitution process continued at the expense of foreign indebtedness. In the late 1970s, the situation of the balance of payments worsened dangerously due to the second oil shock, affecting imports of capital and intermediate goods, and other inputs used by local industries. That resulted in decreasing growth rates of the value added in the manufacturing sector, and a very high idleness level of businesses. With its sector completely stagnant due to lack of foreign exchange to import intermediate and capital goods, the industry's performance was far below expectations.

Nigeria, Kenya, and Zambia - of all the African countries - were the ones which became more industrialized; in the other countries, there was a slight industrial development in the sector of nondurable consumer goods, such as drinks, textiles, etc. It was only in Nigeria and Kenya that a qualitative performance of the manufacturing sector persisted, and the incipient industrial base slowly widened and included durable consumer goods, other intermediate goods, and some capital goods (Forrest, 1982; Arrighi \& Saul, 1973).

The industry led by the State grew substantially in size, but in terms of production, its contribution was very modest. This small growth is due not only to external and internal constraints, but also to low productivity, poor business administration, and the fact that the industry focused more on employment than on business.

\section{DIFFICULTIES IN IMPLEMENTING THE IMPORT SUBSTITUTION INDUSTRY}

The main difficulties in implementing import substitution were: i) obstacles imposed by the agricultural sector; ii) problems with the balance of payments; iii) lack of human capital; and iv) little knowledge of technology.

According to Vitta (1990), the industrial and economic development did not occur as recorded throughout history, with the agricultural sector giving support to the industrial development process by supplying food and raw materials, transferring capital, generating foreign exchange, and providing a consumer market. The

${ }^{10}$ For further details, see Nellis (1986, p. 56). 
only transfer that was possible to achieve from the agricultural sector to the industry was labor, by virtue of a high population growth rate in the region; however, the output per worker which in principle should increase in the agricultural sector, did not occur, thus causing high inconsistency in the economic system. Therefore, with industrial development and larger urban areas, there was a growing need for agricultural goods, either as food for the urban population, or as raw material, to be feasible to continue the industrialization process. The low productivity of the agricultural sector did not allow the growing demand to be met, and even caused problems of food safety in several countries, as reported by FAO (1984).

According to Sutcliffe (1971), when the starting point is a typically primary economy, not only are the workers concentrated in the fields, but also the capital is used in agriculture; industrialization requires, therefore, that part of these resources be transferred to investments in industrial activities.

In Africa, the Government's policy on resource transfer somehow segregated the agricultural sector which - with the reduction in credit lines for farmers, both for planting and purchasing of machines and tools - continued its production at a low capital-labor ratio. Public investments in technological innovation in the agricultural sector were not extended to peasants, either, who were the majority and who grew crops using outdated practices and technology. Moreover, the policy of overvalued exchange rate, aimed at favoring the local industry, led to a reduction in the competitiveness of African agricultural exports in the international market. These aspects discouraged crop production not only for export, but also for domestic consumption. The agricultural sector was, therefore, unable to give support to industrial growth as the aspects above produced i) farmers with low income, not creating demand or market for manufactured goods in the cities; ii) impossibility to increase the supply of foodstuffs and raw materials to meet a growing demand of the industry and larger urban population; iii) due to declining terms of trade, inability of the agricultural sector to export the required amount to meet the needs of the industry for imports of capital and intermediate goods.

The exchange constraint affected imports of inputs and other resources required for industrial production, thus imposing three obstacles to industrial development: first, the production level could only be maintained through adequate import level of inputs; second, the investments and industrial activities did not have to necessarily be linked to the remaining sectors and economic activities, as the way it was organized, the industry depended, almost entirely, on foreign countries although very superficial, there was a connection between industries and other local sectors, for example, such as agriculture; third, as imports consisted of inputs that were essential to production and investment, difficulty in acquiring enough foreign exchange to import them resulted in idle capacity, job/income reduction and, in consequence, a decline in the Sub-Saharan African economies.

The human capital problem is a factor that was identified at the time Africa gained independence, and one which could not help but have a negative effect on industrial development, as it directly or indirectly affected its implementation. The shortage of human capital and lack of skilled staff with some experience in bureau- 
cracy adversely affected the business organization - especially that of state-owned companies, the coordination of production processes, and particularly the way public ones were run. Technical deficiency in engineering affected the production mechanism in factories and machine maintenance work; these direct effects on the industry resulted in a highly inefficient sector. Shortage of staff also affected the industry indirectly, as the Government was unable to devise a suitable strategy and plan for the growth of the sector. Without qualified executives, it was difficult to establish an institutional structure and bureaucracy capable of regulating and administering the import substitution process (Gulhati, 1990; Helleiner, 1994). According to these authors, Governmental agencies - which were created at the heart of the industrial policy to compensate for a lack of an organized capital market - were also inefficient at allocating the capital (from foreign aid, the agricultural, mining and oil sectors) to the industries.

Another obstacle to industrial development, according to Vitta (1990), was the technological level of the industry, which also stayed very low. Learning about technology and acquiring technological advances were very costly processes, although technology was an integral part of the capital goods imported. In this author's opinion, although they fully recognized the need to introduce advanced technology — with state-of-the-art methods and procedures for the production and distribution of goods and services - the Governments did not put much effort into setting a specific goal and defining the plan of action in order to achieve that goal. Naturally, the reasons behind that could be attributed to the lack of a clear technological policy and planning for the sector, as well as an eminent lack of funds.

Some authors suggest that the African import substitution process was not successful because the industrial policy occurred amidst economic policies adopted by Governments that neither planned their actions, nor foresaw the consequences of their actions. Bruton (1998) points outs that the measures taken for implementation of the import substitution industry in African countries lacked economic rationality, and were much more ad hoc than in any other part of the world. Vitta (1990) states that the development of the African industry depended on results left to chance, the direct consequence of steps taken without any concern over cause and effect. However, De Valk (1994, p. 229) has a different opinion. He suggests that there was an industrial development policy and planning, but it is questionable whether that policy was adequate. It seems to us that the failure of the African industrialization was closely related to the fact that the process went beyond the limits of human resource capacity, endowment of financial resources, and market size. In addition to these aspects, there was a high level of interference from the State in the market and a poorly developed economic infrastructure.

\section{RESULTS OF IMPORT SUBSTITUTION}

Some indicators show that the industrial development in Africa was inferior to the industrial progress made by other peripheral countries which adopted the 
same strategy. In 1960, the developing countries accounted for $6.9 \%$ of value added in global manufacturing, this share rising to $8.8 \%$ in $1975 .{ }^{11}$ Sub-Saharan Africa's share in 1960 was of only $0.7 \%$, and in $1975,0.8 \%$ (Fransman, 1982, p.1). It can be observed on Table 2 that follows that the increase in Africa's share of value added in global manufacturing was almost nil between 1960 and 1976.

Table 2: Share of Sub-Saharan African Countries and other Developing Countries in Global Manufacturing, Value Added (\%)

\begin{tabular}{|c|c|c|c|}
\hline Year & Sub-Sahara & Other Developing Countries & Total \\
\hline 1960 & 0.70 & 6.20 & 6.90 \\
\hline 1970 & 0.69 & 6.64 & 7.33 \\
\hline 1971 & 0.70 & 6.60 & 7.30 \\
\hline 1972 & 0.70 & 7.10 & 7.80 \\
\hline 1973 & 0.71 & 7.21 & 7.92 \\
\hline 1974 & 0.72 & 7.54 & 8.26 \\
\hline 1975 & 0.80 & 7.96 & 8.76 \\
\hline 1976 & 0.71 & 7.96 & 8.67 \\
\hline
\end{tabular}

Source: Fransman (1982, p. 2)

Figure 1 below shows that Sub-Saharan Africa is a region with one of the smallest shares in global manufacturing. Nonetheless, the sector grew at fairly high average rates of about 7\% per year between 1960 and 1980. From 1985 on, manufacturing growth declined due to structural adjustment.

Figure 1: Manufacturing, Value Added of Some Regions in the World

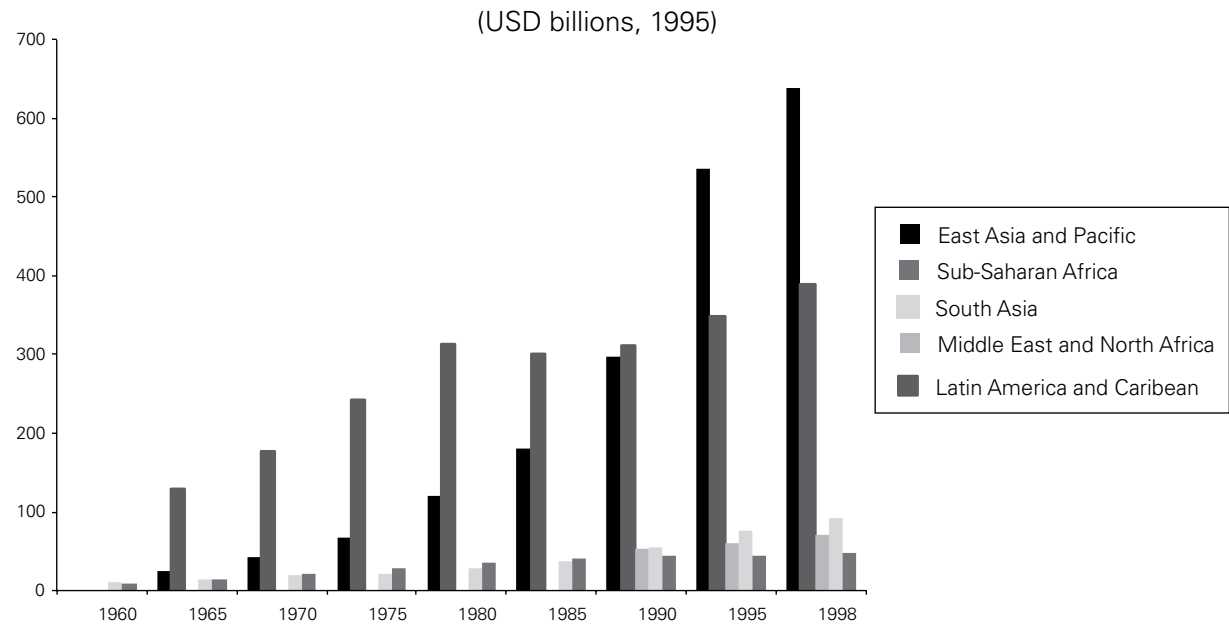

Source: Drawn from the World Bank (2000).

\footnotetext{
${ }^{11}$ For the same period, the corresponding values for industrialized economies are $75 \%$ and $63.7 \%$
} respectively, and for centrally planned economies, $18 \%$ and $28 \%$ respectively (Fransman, 1982, p. 1). 
Another indicator of African manufacturing's performance is the average share of Sub-Saharan Africa in export of manufactured goods in global industrial exports. This indicator demonstrates that exports of Sub-Saharan Africa's manufacture fell from $1.12 \%$ in $1970-1971$ to $0.60 \%$ in $1975-1976$ (Fransman, 1982, p. 2).

In the mid-eighties, after 25 years of leaning towards an industrialization strategy through import substitution, the African manufacturing sector was just a small enclave in the economy of the region, accounting for only $7.5 \%$ of GDP in 1983. In several countries, the share of manufacturing in GDP, compared to that in the 1960s, even decreased, indicating that the process receded throughout time (Iheduru, 1999).

According to the World Bank (1994), the average annual growth rate of manufacturing in Sub-Saharan Africa dropped sharply — from 4.3\% between 1970 and 1980 , to $1.4 \%$ between 1980 and 1992 .

Faced with so many constraints, the results could not be any better; in fact, the development of the African industrial park was poor, gaining peculiar features through the interaction between structural aspects of the region, external constraints and difficulties with domestic policies. First, the cost of production was high, as it depended mostly on imports of inputs and machines. The shortage of inputs, such as water and power, caused by the rapid growth of industry and population in relation to the growth of infrastructure, made production costs rise even more. ${ }^{12}$ Second, plants were oversized, poorly designed, and badly located as a result of Governmental corruption; and production units financed and built by international agencies. ${ }^{13}$ Most of these production units were inefficient because of their obsolete machinery, which was either donated by partner countries or bought within the scope of the aid the project was part of. Third, inefficiency was also connected with the type and quality of the local administration, which lacked capability, experience, and training. In addition, management was not well qualified, and the labor force was unskilled and illiterate. And last, the low income level, the market size of each country, as well as the closing of some borders between countries of the region due to civil unrest, and the weak development of the transportation infrastructure connecting the neighboring countries did not allow economies of scale. These aspects, added to overvalued exchange rates - which reduced the competitiveness of crop exports, causing a shortage of foreign exchange for imports of machines and raw materials - and oversized plants, resulted in excess industrial capacity and failure.

\footnotetext{
12 It discouraged foreign investments, for these costs were greater than the tax incentives.

${ }^{13}$ According to Austen (1987) and Fransman (1982), these agencies did not have information what the needs of these countries were, and financing for these production units was associated with trading interests.
} 


\section{FINAL CONSIDERATIONS}

We have seen that, dating back to 1920 , it was necessary for African economies to substitute imports, while still under colonial rule. However, the policy concerning the colonies - interested in keeping Africa as a captive market for European manufactured goods - blocked their attempts at implementing industry, thus preventing the process from succeeding. After independence, most African countries believed industry was the engine of economic growth that would lead them to development. Therefore, they adopted an industrialization strategy as a substitute for importation in light of Latin America's experience.

However, contrary to what occurred in Latin American countries, Africa's strategy failed due to great structural constraints of the domestic market, and strong external restrictions. Physical and human capital, available in Sub-Saharan Africa, was much smaller than that of other underdeveloped countries. The literacy rate was very low, labor unskilled, and experienced management very restricted. Moreover, the institutions and bureaucracies intended for development were fragile, as a reflection of the shortage of qualified personnel.

The low domestic savings level and declining terms of trade for exports of primary goods caused the investments in the industrial sector to be below expectations, even with the help of foreign aid. This constellation of constraints and the dynamic of the process itself paradoxically made the import substitution strategy increase (instead of reducing) Africa's dependence on developed countries and the international market.

The African industrial park was characterized as being inefficient and using outdated technology, and operated below its capacity due to oversizing, lack of economies of scale, and the great need to import inputs and machines (which were not generally replaced as the shortage of foreign exchange prevented their importation). Whatever effort put into the industrial sector was surpassed by the problems above, thus making production costs far too high. Under such conditions, the World Bank - which in 1981 had presented Sub-Saharan Africa as the least industrialized region in the world - has not changed its opinion in subsequent reports (World Bank, 1989 and 1994).

Finally, it is important to note that most of the problems in the industrial sector emerged from actions and choices of the political elite: measures towards industrialization through import substitution, and investments in manufacturing and subjacent sectors, were handled as political weapons, either by the Government or the political party. In fact, the domain of industry was a way of legitimating the politicians rather than a rational economic policy aimed at the development of the industrial sector. The measures were somehow randomly taken, and sooner or later would end in failure of the sector, as well as in a generalized economic crisis, as the entire region had a highly deficient and inefficient sector financed by the external debt. 


\section{REFERENCES}

ARRIGHI, G. and SAUL, J. (1973), Essays on the Political Economy of Africa, Monthly Review Press.

AUSTEN, R. A. (1987), African Economic History: Internal Development and External Dependency, London: James Currey.

BRUTON, H. J. (1998), “A Reconsideration of Import Substitution”, Journal of Economic Literature, $\mathrm{N}^{\circ}$ 2, Vol. 32, p. 903-936.

COULSON, P. (1982), “The State and Industrialization in Tanzania”, in Fransman, M., (1982), Industry and Accumulation in Africa, Heinemann International Literature \& Textbooks.

D’ALMEIDA, A.F. (1986), “La Privatization des Enterprises Publiques en Afrique au Sud du Sahara”, Le Mois en Afrique, Nos. 245 and 246, June and July.

DE VALK, P. (1994), "A Review of Research Literature on Industry in Sub-Saharan Africa under Structural Adjustment”, in VAN DER HOEVEN, R., and VAN DER KRAAIJ, F., Structural Adjustment and Beyond in Sub-Saharan Africa, Currey for Ministry of Foreign Affairs, p. 227-239.

FAO (1984), Food and Agricultural Organization, Report.

FORREST, T. (1982), "Recent Development in Nigerian Industrialization”, in Fransman, M., (1982), Industry and Accumulation in Africa, Heinemann International Literature \& Textbooks, p. 323-344 .

FRANSMAN, M. (1982), Industry and Accumulation in Africa, Heinemann International Literature \& Textbooks.

GHAI, D. (1991), The IMF and the South: The Social Impact of Crisis and Adjustment, London: Ed. Zed Books.

GULHATI, R. (1990), “Who Makes Economic Policy in Africa and How?”, World Development, Vol. $18, \mathrm{~N}^{\circ} 8$, p. 1147-1161.

GULHATI, R. \& SEKHAR, U. (1982), “Industrial Strategy for Late Starters: The Experience of Kenya, Tanzania and Zambia”, World Development, Vol. 10, N 11, p. 949-972.

HELLEINER, G. K. (1994), "From Adjustment to Development in Sub-Saharan Africa”, UNCTAD Review.

HERBST, J. (1990), “The Structural Adjustment in Africa”, World Development, Vol. 18, No 7, p. 949 $-958$.

IHEDURU, O. M. (1999), The Politics of Economic Restructuring and Democracy in Africa, Greenwood Press.

KILBY, P. (1975), “Manufacturing in Colonial Africa”, in DUIGNAN, P. \& GANN, L., H., (eds.), Colonialism in Africa, 1870-1960, Vol. 4, London: Cambridge University Press.

MKANDAWIRE, T. \& SOLUDO, C. C. (1999), Our Continent, Our Future: African Perspectives on Structural Adjustment", Trenton, NJ: Africa World Press.

NELLIS, J. R. (1986), “Public Enterprises in Sub-Saharan Africa”, World Bank Discussion Paper N ${ }^{\circ}$, Washington DC.

NIXON, F. (1982), “Import Substituting Industrialization”, In Fransman, M. (1982), Industry and Accumulation in Africa, Heinemann International Literature \& Textbooks, p. 38-57.

PAULSON, J. A. \& GAVIN, M. (1999), “The Changing Role of the State in Formerly-Socialist Economies of Africa”, In PAULSON, J. A. African Economies in Transition, Vol. 1, St. Martin's Press.

PEARSON, D. S. (1969), Industrial Development in East Africa, Oxford University Press.

SHORT, R. P. (1984), “The Role of Public Enterprise: An International Statistical Comparison”, in Floyd, R., et al., Public Enterprises in Mixed Economies: Some Macroeconomic Aspects, International Monetary Fund, Washington DC.

STEIN, H. (1992), "Deindustrialization, Adjustment, the World Bank and the IMF in Africa", World Development, Vol. 20, N 1, p. 83-95.

STONEMAN, C. (1982), "Industrialization and Self-Reliance in Zimbabwe”, in Fransman, M., (1982), Industry and Accumulation in Africa, Heinemann International Literature \& Textbooks.

SUTCLIFFE, R., B. (1971), Industry and Underdevelopment, Addison-Wesley Publishing Company. 
VITTA, P. B. (1990), “Technology Policy in Sub-Saharan Africa: Why the Dream Remains Unfulfilled”, World Development, Vol. 18, No 11, p. 1471-1480.

WORLD BANK (1989), Sub-Saharan Africa: From Crisis to Sustainable Growth - A Long-Term Perspective Study, Washington, DC: The World Bank. (1994), “Adjustment in Africa: Reforms, Results and the Road Ahead”, A World Bank Policy Research Report, Washington, DC: The World Bank. (2000), The World Bank Indicators, Washington, DC: The World Bank. 